\title{
PHENOMENON OF VIOLENCE IN SOCIOLOGY
}

УДК 316.624

DOI https://doi.org/10.32843/2663-

5208.2019.9.2

Opoc О.Б.

к. соц. н.,

старший викладач кафредри психології

Мукачівський державний університет
У статті розкрито ключові аспекти френомена насильства з точки зору сочіологічноі науки. Уточнено специфріку розуміння насильства на макро-, мезо- та мікрорівні. Відзначено значну предметну різноманітність підходів до тлумачення насильства у соціології. Природа насильства може бути продуктом як реальних протиріч, так і суто символічних процесів. Воно може трактуватися в якості як глибинного джерела соціальних трансформацій, так і прояву соціальних девіацій. Виокремлено два основні альтернативні підходи до трактування насильства: консеквентний та девіантологічний.

Соціологія має найбільш розгалужене поняття насильства. Починаючи від «надіндивідуальної природи соціального примусу» Е. Дюркгейма до модерністської «концепціі міжцивілізаційного насильства» С. Хантінгтона. Природа насильства, з точки зору соціологів, може бути продуктом як реальних протиріч, так і суто символічних процесів. Воно може трактуватися в якості як глибинного джерела соціальних трансформацій, так і прояву соціальних девіацій. Таким чином, насильство має бути об'єктом комплексного міждисциплінарного дослід ження, яке інтегрує фрілософрські, юридичні, соціологічні, психологічні та медичні підходи до аналізу цього феномена.

Огляд соціологічних підходів до вивчення насильства дозволяє визначити дві основні стратегіі, в межах яких ие відбувається. Зәідно з однією насильство - важлива складова частина соціального порядку, його застосування є об'єктивною необхідністю приборкати соціальний хаос і безлад. Таку стратегію слід вважати універсалістською. Згідно з другою стратегією дослідження насильство діяльність із метою обмеження реалізації найважливіших життєвих прав і свобод людини. Ця стратегія активно розвивається в межах предмету соціології особистості та правознавчих наук. Стратегію, яка орієнтована на права і свободи особистості, треба вважати лібертаріанською. Дана стратегія є альтернативною відносно дослідницької стратегіі універсалізму, а також складовою частиною авторитарного стилю управління

Підходи трактування феномена насильства відрізняються значною предметною різноманітністю. Принципові розбіжності між розглядом насильства в широкому і вузькому сенсах вимагають певних засобів їх інтеграuії. Насильство стає предметом дослідження різних наук, зокрема соціології девіантного поводження, методологія яких $є$ занадто широкою та недостатньо розробленою. Важливим недоліком поняття фрізичного насильства $є$ дистанціювання процесу пояснення і його розуміння як суспільного явища. Ключові слова: насильство, фрізичне насильство, аналіз, науковий підхід, соціальна система, суспільство.
The key aspects of the phenomenon of violence in terms of sociological science have been revealed the article. Specifics of the understanding of violence at the macro, meso and micro levels have been specified. A significant variety of approaches to the interpretation of violence in sociology have been defined. The nature of violence can be both a product of real contradictions and purely symbolic processes. It can be interpreted as both a deep source of social transformations and the manifestation of social deviations. Two main alternative approaches to the interpretation of violence consequent and deviantologic have been distinguished.

Sociology has the most extensive concept of violence. Starting from the "subindividual nature of social coercion" by E. Durkheim [2] to the modernist "concept of inter-civilization violence" by $S$. Huntington [3]. The nature of violence, from the point of view of sociologists, can be both a product of real contradictions and purely symbolic processes. It can be interpreted as both a deep source of social transformations and the manifestation of social deviations.

Thus, violence should be the subject of a comprehensive multidisciplinary research that integrates philosophical, legal, sociological, psychological and medical approaches to the analysis of this phenomenon.

An overview of sociological approaches to the study of violence allows to identify two major strategies within which this is happening. According to the first, violence is an important component of the social order, its application is an objective need to curb social chaos and disorder. Such a strategy should be considered as universalist. According to the second research strategy, violence is an activity aimed at limiting the implementation of the most important human rights and freedom. This strategy is actively developing within the subject of sociology of personality and law sciences. A strategy that focuses on the rights and freedom of the individual must be considered as libertarian. This strategy is an alternative not only to the research strategy of universalism, but also to the component of the authoritarian style of management.

Approaches to interpretation the phenomenon of violence are characterized by considerable subject diversity. Principal differences between the consideration of violence in the broad and narrow sense require some means of its integration. Violence becomes the subject of the study of various sciences, in particular the sociology of deviant behavior, the methodology of which is too broad and underdeveloped. An important disadvantage of the concept of physical violence is the distancing of the process of explanation and its understanding as a social phenomenon.

Key words: violence, physical violence, analysis, scientific approach, social system, society. 
Постановка проблеми. Людство намагалося зрозуміти потенціал насильства завжди. Особливо важливо ідентифікувати якості та соціальні координати насильства в умовах сьогодення, коли суспільство зазнає глобалізаційних трансформацій. Постає питання про однозначність негативного та девіантного забарвлення насильства. Уявлення про насильство як застосування сили по відношенню до людей та їх власності виглядає достатньо очевидним і поширеним на побутовому рівні свідомості, однак це не сприяє його науковому розумінню. Розуміння насильства як соціального феномена дає можливість зрозуміти його функції, сприяє формуванню превентивних та корекційних стратегій реакції.

Аналіз останніх досліджень і публікацій. Проблеми насильства та агресії ще у другій половині XIX століття у своїх наукових працях порушували такі вчені, як Л. Сабінін, О. Герд, І. Сікорський, П. Каптєрєв, О. Зак, Д. Дріль. Упродовж останніх років цієї проблеми торкалися вітчизняні та закордонні соціологи: М. Фуко, Е. Гіденс, Р. Арон, Т. Авельцева, А. Бова, К. Вільсон, Ш. Волін, Т. Журавель, А. Зелінський, Г. Ковганич, О. Колб, В. Кривуша, В. Кудрявцев, О.Волянська, Л. Герасіна.

Постановка завдання. У своїй роботі ми спробували виявити основні моделі інтерпретації феномена насильства в соціології. Для досягнення мети поставлено такі завдання:

1. Уточнити специфіку поняття насильства з точки зору соціологічної науки.

2. Окреслити трактування насильства в різних соціологічних парадигмах.

3. Розкрити основні аспекти соціологічної інтерпретації фізичного насильства як найбільш очевидного виду насильства.

Виклад основного матеріалу дослідження. Насильство, як фундаментальний соціальний феномен, треба розглядати в широкому і вузькому сенсі. Насильство у широкому сенсі - це один із способів задоволення потреб. Воно відбувається на макрорівні, як цілком легітимний та інституціалізований примус або протизаконне військове загарбництво. Насильство на мезорівні припускає як різного роду види спровокованого колективного самозахисту, так і невиправдані конфлікти між окремими соціальними групами і спільнотами. В основі такого насильства лежить прагнення певної частини людей до домінування і панування над іншими, а також боротьба за життєві ресурси, в тому числі за владу. Насильство на мікрорівні проявляється у формі свідомого впливу на особу поза її волею та бажанням, що призводить до обмеження чи втрати нею можливостей для власного розвитку. Як зазначає Л. Герасіна: «Насильство як асоціальне явище не тільки формує трагічні обставини для багатьох людей, але й створює криміногенні ситуації, які передують кримінальним злочинам проти безпеки, здоров'я і життя людини, що в цілому руйнує фундамент стабільності суспільства» [1].

У вузькому значенні насильство - це завдання особі будь-якої шкоди. Фізичне насильство у вузькому сенсі - це, перш за все, заподіяння особі прямої фізичної шкоди. Заподіяння психічної, економічної або моральної шкоди має бути пов'язане з примусом, який обмежує волю іншої особи, позбавляє її свободи пересування. У силу того, що насильство завжди несе порушення здоров'я або загрозу його порушення, воно проявляється в якості соціально небезпечного явища. Але значні розбіжності між широким і вузьким сенсами розуміння насильства вимагають певних засобів їх інтеграції.

Дослідницькі підходи до феномена насильства відрізняються значною предметною різноманітністю. Так, у соціальній філософії насильство розуміється як застосування сили або загроза її застосування, як зведення сили в закон людських відносин. Правознавці акцентують увагу на фактах порушення правових норм. Всесвітня організація охорони здоров'я визначає насильство як «навмисне застосування фізичної сили або влади, дійсне або у вигляді загрози, спрямоване проти себе або проти іншої особи, групи осіб або громади, результатом якої $\epsilon$ тілесні ушкодження чи високий ступінь їх вірогідності, смерть, психологічна травма, відхилення в розвитку або різного роду збитки». Причому насильство в медичному аспекті класифікується за трьома типами: спрямоване проти самого себе, колективне і міжособове [2, с. 2].

Соціологія має найбільш розгалужене поняття насильства. Починаючи від «надіндивідуальної природи соціального примусу» Е. Дюркгейма [3] до модерністської «концепції міжцивілізаційного насильства» С. Хантінгтона [4]. Природа насильства, з точки зору соціологів, може бути як продуктом реальних протиріч, так і суто символічних процесів. Воно може трактуватися в якості як глибинного джерела соціальних трансформацій, так і прояву соціальних девіацій.

Таким чином, насильство має бути об'єктом комплексного міждисциплінарного дослідження, яке інтегрує філософські, юридичні, соціологічні, психологічні та медичні підходи до аналізу цього феномена. Міждисциплінарні дослідження насильства концентрують увагу як на об'єктивній природі насильства, так і на його суб'єктивних проявах, а консеквентні підходи закономірно доповнюються деонтологічними напрямками дослідження насильства.

До основних напрямків дослідження і пояснення об'єктивної природи насильства відносяться: містико-езотеричні рухи, етологічні, 
антропологічні та біологічні теорії. Їх методологічною основою $є$ класична детерміністська парадигма, традиційний причинний аналіз, визнання успадкування потягу до насильства та його консеквентної природи. Консеквентність (consequens), як послідовність, своїм наслідком має залежність від попередньої причини або системи, яка є наслідком попередніх обставин. Наявність консеквенції може бути підставою як для фаталізму, так і для наполегливого раціонального вивчення насильства як закономірного соціального явища.

Альтернативою консеквентному підходу в дослідженні насильства $є$ девіантологія, яка розглядає насильство як відхилення від норми або ідеалу. Слабким місцем девіантології єінтуїтивність, або конвенційність поняття норми. Завдяки конвенції норму не можна визнати чиєюсь суб'єктивною вигадкою. Норма погоджується на мега- або мезосоціальному рівнях. Проте на мікрорівні, де можливо інтуїтивне визнання норм насильницького поводження, вона може бути суб'єктивним явищем. Формування деонтологічної за змістом девіантології $€$ закономірним наслідком руйнування підходу консеквентного. При цьому визначення девіантності поводження спільноти чи окремої особистості повинно здійснюватися в порівнянні з консеквентними формами поведінки, які відповідають визнаним нормам суспільного життя.

Поняття насильства $€$ предметом розгляду в рамках різних соціологічних парадигм. У контексті конфліктологічної парадигми (К. Маркс, Г. Зіммель, Л. Козер, Р. Дарендорф) насильство - закономірний продукт соціальної диференціації (стратифікації), панування і підпорядкування [5; 6]. Природа насильства одних над іншими полягає в загостренні протиріччя між рушійними силами соціальних змін та консервації, нерівного статусного становища людей та соціальних груп. У силу об'єктивності соціальних конфліктів революційне насильство $€$ закономірним і суспільно виправданим явищем. Насильство запобігає окостенінню соціальних систем, відкриваючи шлях соціальним змінам та інноваціям.

Головною особливістю насильства в контексті структурно-функціональної парадигми (А.Р. Редкліфф-Браун, Б. Малиновський, Т. Парсонс, Р. Мертон) є його визнання наслідком дисфункції системи, відхиленням від норми або нелегітимним діянням. При цьому «правила функціонування соціальної системи мають забезпечувати виживання як самої системи, так і її складових частин». Відповідь на питання «Як можна погодити універсальні та партикулярні аспекти життя соціальної системи?» одночасно вимагала відповідь на питання про легітимність насильства. Зрозуміло, що соціальна система в процесі соціалі- зації повинна спиратися на соціальні інститути та інші примусові засоби протидії відхиленням проти соціальних норм.

Згідно з етологічною теорією (К. Лоренц) природа насильства полягає у його ототожненні $з$ успадкованою людиною природною агресивністю. 3 точки зору етологічної теорії «насильство і агресія - прояви людиною природжених інстинктів боротьби за виживання. Вони можуть розглядатися як такі, що сприяють виживанню спільнот і біологічних видів» [7]. У рамках концепцій біологічної схильності людини до насильства і агресії насильство може розглядатися як «природний атавізм» (Ч. Ломброзо) або як «засіб вдосконалення людини» (Ф. Ніцше).

Погляд на природу насильства з позиції психоаналітичної теорії (З. Фрейд, К. Хорні, Е. Фромм) іноді позиціонувалося в якості альтернативи його ідеалістичному (М. Вебер) та економічному (К. Маркс) розумінню. Проте психоаналітична теорія, яка пояснює природу насильства з конфлікту неусвідомлених психічних процесів та культурних норм, близька до біологічно-еволюційної школи. Незалежно від конкретики того, в чому полягає природа насильства, «неспроможності розв'язання сексуальних колізій» (З. Фрейд) чи «основного страху» (К. Хорні), вона спрямована, перш за все, проти свого носія. Поведінка носія агресії $€$ руйнівною, оскільки якщо енергія танатосу не буде звернена назовні, це в кінці кінців зруйнує самого носія [8; 9].

Принципово інший спосіб дослідження насильства запропоновано в контексті інтерпретативної парадигми. Символічний інтеракціонізм (Дж.Г. Мід, Г. Блумер) робить головний акцент на аналіз соціальних взаємодій на основі символічного змісту. Причому найбільша увага приділяється головному символічному засобу взаємодії - мові. У силу того, що за соціальними символами приховується порівняння діяльності індивіда із соціальними нормами, символічний інтеракціонізм піднімає проблему легітимного символічного насильства. Воно набуває вигляду реалізації «драматичної метафори», яка є продуктом взаємодії символів психодраматичної дії певних «акторів» і «масок» за певним «сценарієм» $[10 ; 11]$.

Огляд соціологічних підходів до вивчення насильства дозволяє визначити дві основні стратегії, в межах яких це відбувається. Згідно з однією насильство - важлива складова частина соціального порядку, його застосування $€$ об'єктивною необхідністю приборкати соціальний хаос і безлад. Таку стратегію слід вважати універсалістською. Вона віддає перевагу універсальним процесам, які відбуваються на макросоціальному рівні. Завдяки статусу об'єктивної необхідності насильство заради соціального порядку справедливості 
чи прогресу може бути легалізовано. 3 точки зору універсалістської стратегії насильство $€$ невід'ємним атрибутом суспільного життя.

Згідно із другою стратегією дослідження насильство - це діяльність із метою обмеження реалізації найважливіших життєвих прав і свобод людини. Ця стратегія активно розвивається в межах предмету соціології особистості та правознавчих наук. Стратегію, яка орієнтована на права і свободи особистості, треба вважати лібертаріанською. Ця стратегія $є$ альтернативною відносно дослідницької стратегії універсалізму, а також складовою частиною авторитарного стилю управління. У девіантології насильство $є$ близьким за значенням із поняттями «агресивна поведінка» та «агресивні дії». Агресивно-асоціальна поведінка, як така, що спрямована назовні, завжди носить насильницький характер. Таке насильство спровоковане негативними емоціями суб'єкта насильницького акту, такими як: розпач, злість, образа [12].

Феномен насильства може приймати різні форми, але переважно репрезентується через взаємодію двох сторін: насильника та жертви. Онтологія і феноменологія насильства на цьому рівні повністю співпадають. Розбіжності між онтологією і феноменологією насильства виникають у випадку спроби визначення поняття сили. Безпосереднє застосування сили проти іншого - дія фізичного рівню. Воно може бути як самозахистом, так і проявом фізичного насильства проти іншої особи. Розділити ці явища на рівні феномена дуже складно. Феноменологічно тотожні явища застосування фізичної сили можуть бути онтологічно різними.

На думку В.В. Савчука, «якщо у визначенні насильства дослідник не ставить онтологічних питань, він, не бажаючи того, завжди опиняється у пастці ідеології». Більш того, «коли аналіз насильства відбувається поза онтологічною та епістемологічною проблематикою, тоді насильство мислиться іманентним моралі та праву» [13, с. 476]. Таке дослідження намагається дати відповідь на запитання, якою мірою можливо зменшити або уникнути насильства у суспільстві, як зробити легітимне (державне або педагогічне) насильство більш контрольованим. Онтологія дослідження дозволяє просуватися на глибинні рівні пізнання та витлумачення явищ об'єктивної дійсності, що існують незалежно від цінностей персоніфікованої свідомості та корпоративних інтересів окремих соціальних груп.

Онтологічний підхід виходить з методологічного припущення, що насильство $є$ невід'ємним атрибутом суспільного життя. Насильство іманентно світові, як іманентно йому існування фізичного тіла і фізичної сили. Онтологічний підхід, на відміну від аксіологічного чи правоз- навчого, не зупиняється на оцінці феномена насильства, а намагається відкрити його природу та механізм утворення. Диференціація онтологічного і феноменологічного підходів створює умови продуктивного аналізу певного балансу насильства та ненасильства у суспільстві. За деяких умов об'єктивні аспекти насильства можуть стати підставою для вимірювання рівню суспільної злагоди та «моральності суспільства» [14, с. 112].

Ототожнення фізичного насильства із проявами фізичного побиття або іншою шкодою фізичного характеру справляє враження очевидності цього явища. Фізичне насильство це випадки, коли проти людини застосовують такі дії: нанесення побоїв, тілесних ушкоджень, удушення, ляпаси, штовхання, жбурляння, брутальне хватання, використання зброї та багато іншого. Великий тлумачний словник сучасної української мови ототожнює поняття фізичного насильства з насильством взагалі. «Насильство - 1. Застосування фізичної сили до кого-небудь. 2. Застосування сили для досягнення чого-небудь; примусовий вплив на когось, щось» [15, с. 735]. Із контексту похідних понять важко зрозуміти, що $є$ головною ознакою насильства: силова перевага чи зовнішнє підпорядкування волі, мимовільні непереборні рухи чи наявність шкідливих наслідків для організму, невідповідність ситуації емоційному стану постраждалого чи психічні розлади.

Фізичне насильство - це поняття, яким користуються різні фундаментальні науки, серед яких: юриспруденція, соціологія, політологія, психологія, медицина і філософія. Фізичне насильство все більш стає об'єктом уваги практико-технологічних дисциплін, таких як соціальна робота та безпека життєдіяльності людини та суспільства. Це пов'язано з багатогранністю феномена, який проявляється практично у всіх формах суспільного життя. Негативний зміст поняття вимагає не тільки фундаментальних досліджень, але й практичних рішень у питаннях нейтралізації його проявів. Різноманітні підходи до вирішення питань фізичного насильства інтегруються в межах комплексної науки про насильство - віолонтології (або вайолентології, від лат. violence - насильство).

Насильство може бути результатом експансії в область персональної значущості та домінування, особливо тих, хто її позбавлений або вважає себе таким. Тоді фізичне насильство це спроба довести свою значущість фізичними засобами. Фізичне насильство - це результат подвійної обділеності суб'єкта. По-перше, це результат низької самооцінки суб'єктом власної значущості та неспроможності. При цьому занижена самооцінка, що формується у вузькому колі інгрупи, може бути помилковою та штучною. Незалежно від походження та рівня 
об'єктивності занижена самооцінка утворює першу складову частину проявів фізичного насильства. По-друге, спроби задоволення потреби в персональній значущості мають бути обмежені можливостями застосування нефізичних засобів її досягнення. Відповідно, сила як джерело діяльності, спонукання та могутності впливу перетворюється у фізичне насильство штучно, за допомогою оцінки та заборони.

Як правило, фізичне насильство вчиняється діями особи. Однак відомі прояви фізичного насильства і шляхом пасивної поведінки або бездіяльності. Наприклад, ненадання тривалий час необхідних послуг особі, яка перебуває в безпорадному стані, із вчиненням у такий спосіб умисного вбивства. Особа, яка вчиняє фізичне насильство, може усвідомлювати його характер, передбачати наслідки або здійснювати його з необережності. Ідентифікація прояву фізичного насильства за ознакою попереднього умислу здається дуже складною. До того ж за формою прояву фізичне насильство може бути правомірним або протиправним. До категорії правомірного фізичного насильства відносять: методи фізичного виховання, необхідну оборону, заходи затримання злочинця, крайню необхідність, виконання службового обов'язку, проведення хірургічної операції, наукового експерименту та інше. Протиправним або злочинним проявом фізичного насильства $\epsilon$ бандитизм, розбій, умисне вбивство, умисне заподіяння тілесних ушкоджень, зґвалтування, грабіж, вимагання (рекет) та інше.

Висновки. Підходи трактування феномена насильства відрізняються значною предметною різноманітністю. Природа насильства може бути продуктом як реальних протиріч, так і суто символічних процесів. Воно може трактуватися в якості як глибинного джерела соціальних трансформацій, так і прояву соціальних девіацій. Виокремлено два основні альтернативні підходи до трактування насильства: консеквентний та девіантологічний. Слабким місцем девіантології $€$ інтуїтивність або конвенційність поняття норми. Завдяки конвенції норму не можна визнати чиєюсь суб'єктивною вигадкою. Принципові розбіжності між розглядом насильства у широкому і вузькому сенсах вимагають певних засобів їх інтеграції. Насильство стає предметом дослідження різних наук, зокрема соціології девіантного поводження, методологія яких є занадто широкою та недостатньо розробленою. Епістемологія насильства набуває нахилу в бік його деонтологізації, домінування феноменологічних підходів над онтологічними. Важливим недоліком поняття фізичного насильства є дистанціювання процесу пояснення і його розуміння як суспільного явища.
Вибудовуючи систему дослідження насильства та алгоритм превентивних заходів, слід звернути увагу, що насильство може бути детерміновано як внутрішніми (жорстокість, агресія, бажання самоствердитися), так і зовнішніми спонуками (захист, негативний вплив оточення), а також впливом зовнішнього оточення.

\section{ЛІТЕРАТУРА:}

1. Герасіна Л. Насильство як соціальна деструкція. Вісник Харківського національного універсиmету В.Н. Каразіна № 1148. Серія: «Соціологічні дослідження сучасного суспільства: методологія, теорія, методи». Вип. 34. Харків. 2015. С. 35-41.

2. Травматизм и насилие в Европе. URL www.euro.who.int/_data/assets/pdf_file/0008/98405/ E87321R.pdf-.

3. Дюркгейм Э. Социология: её предмет, метод, предназначение / Пер., предисл., послесл. и примеч. Госрман Александр Бенционович ; Кол. авт. Государственный университет - Высшая школа экономики, 3-е изд., доп. и испр. Москва : Терра - Книжный клуб, 2008. 399 c.

4. Хантингтон С. Кто мы? Вызовы американской национальной идентичности / Пер. с англ. А. Башкирова. Москва : Изд-во АСТ: Транзит книга, 2004. 635 с.

5. Маркс К. Капитал. Критика политической экономии / Под ред. Ф. Єнгельса. Москва : Политиздат, 1978. Т.III, кн. III. Процесс капиталистического производства, взятій в целом. Ч. II. I-IV. 509. 1084 с.

6. Зиммель Г. Экскурс по проблеме: Как возможно общество. Вопросы социологии. Москва, 1993. № 3. C. 16-26.

7. Лоренц К. Агрессия (так называемое «зло»). Москва : Прогресс, 1994. 272 с.

8. Фрейд 3. Введение в психоанализ : Лекции. Москва : Наука, 1989. 352 с.

9. Адлер А. Практика и теория индивидуальной психологи. Москва : Фонд «За эконом. грамотность», 1995. 296 c.

10. Мід Дж. Г. Дух, самість і суспільство з точки зору соціального біхевіориста / Переклад з англійської, передмова та коментарі Т. Корпала. Київ : Український центр духовної культури, 2000. 374 с.

11. Блумер Г. Коллективное поведение. Американская социологическая мысль : Р. Мертон, Дж. Мид, Т. Парсонс, А. Шюц; [Тексты]. Сост. Е.И. Кравченко / Под ред. В.И. Добренькова. Москва : Изд-во Моск. ун-та, 1994. С. 168-215.

12. Змановская Е.В. Девиантология (Психология отклоняющегося поведения). Москва : Академия, 2007. 288 c.

13. Савчук В.В. Насилие в цивилизации комфорта. Антропология насилия. Санкт-Петербург : Наука, 2001. С. 476-496.

14. Назаретян А.П. Антропология насилия и культура самоорганизации : Очерки по эволюционно-исторической психологии. Москва : Издательство ЛКИ, 2007. 256 с.

15. Великий тлумачний словник сучасної української мови (з дод. і допов.) / Уклад. і голов. ред. В.Т. Бусел. Київ ; Ірпінь : ВТФ «Перун», 2005. 1728 с. 